\title{
Optimization of quantitative polymerase chain reactions for detection and quantification of eight periodontal bacterial pathogens
}

Ellen Decat ${ }^{1,2^{*}}$, Jan Cosyn ${ }^{3}$, Hugo De Bruyn ${ }^{3}$, Reza Miremadi ${ }^{3}$, Bart Saerens ${ }^{2}$, Els Van Mechelen ${ }^{1}$, Stefan Vermeulen ${ }^{1}$, Mario Vaneechoutte ${ }^{2}$ and Pieter Deschaght ${ }^{2}$

\begin{abstract}
Background: The aim of this study was to optimize quantitative (real-time) polymerase chain reaction (qPCR) assays for 8 major periodontal pathogens, i.e. Aggregatibacter actinomycetemcomitans, Fusobacterium nucleatum, Parvimonas micros, Porphyromonas gingivalis, Prevotella intermedia, Tanerella forsythia and Treponema denticola, and of the caries pathogen Streptococcus mutans.

Results: Eighteen different primer pairs were analyzed in silico regarding specificity (using BLAST analysis) and the presence of secondary structures at primer binding sites (using mFOLD). The most specific and efficiently binding primer pairs, according to these analyses, were selected for qPCR-analysis to determine amplification efficiency, limit of quantification and intra-run reproducibility. For the selected primer pairs, one for each species, the specificity was confirmed by assessing amplification of DNA extracts from isolates of closely related species. For these primer pairs, the intercycler portability was evaluated on 3 different thermal cyclers (the Applied Biosystems 7300, the Bio-Rad iQ5 and the Roche Light Cycler 480). For all assays on the different cyclers, a good correlation of the standard series was obtained (i.e. $r^{2} \geq 0.98$ ), but quantification limits varied among cyclers. The overall best quantification limit was obtained by using a $2 \mu \mathrm{l}$ sample in a final volume of $10 \mu \mathrm{l}$ on the Light Cycler 480.

Conclusions: In conclusion, the proposed assays allow to quantify the bacterial loads of S. mutans, 6 periodontal pathogenic species and the genus Fusobacterium. This can be of use in assessing periodontal risk, determination of the optimal periodontal therapy and evaluation of this treatment.
\end{abstract}

Keywords: QPCR, Periodontal pathogens, Specificity, Quantification limit, Intercycler portability

\section{Background}

Periodontitis is a multifactorial infectious disease whereby an irreversible destruction of periodontal tissues occurs. This condition is preceded by a reversible state of inflammation of the periodontal tissues, called gingivitis [1]. From a microbiological point of view, this course is characterized by quantitative and qualitative alterations in the microflora of the subgingival environment [2]. The average surface area of the adult human

\footnotetext{
* Correspondence: Ellen.Decat@gmail.com

'Biomedical and Exact Sciences, Faculty of Education, Health \& Social Work, University College Ghent, Keramiekstraat 80, Ghent, Belgium

${ }^{2}$ Laboratory Bacteriology Research, Department Clinical Chemistry, Microbiology \& Immunology, Faculty of Medicine and Health Sciences, University of Ghent, De Pintelaan 185, Ghent B-9000, Belgium

Full list of author information is available at the end of the article
}

oral cavity has been estimated to amount to approximately $215 \mathrm{~cm}^{2}$ [3], presenting a vast surface for microbial colonization. A total number of around 700 microbial species has been estimated to populate the numerous surfaces of the oral cavity [4], and major differences can be observed between subjects and even on a site level within one subject [5]. Although most of these bacteria are commensal microorganisms, numerous bacterial species, including several that cannot be grown in vitro, have been associated with periodontal health and disease, related to biofilm formation [6-10]. Therefore, assessing the bacterial diversity in the subgingival biofilm may be important for the diagnosis and optimized treatment of periodontal diseases. The total number of microbial cells in subgingival plaque from

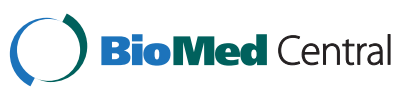


periodontally healthy subjects has been estimated to amount to $3.3 \times 10^{9} \mathrm{cfu} / \mathrm{mg}$, increased to $1.7 \times 10^{10} \mathrm{cfu} / \mathrm{mg}$ for patients with periodontitis, with considerable intersubject variation [11]. This increase in microbial counts is also accompanied by a certain shift in the microbial species present $[12,13]$. Basically, the biofilm continues to develop with increasing biodiversity. So-called periodontal pathogens, mainly including gram negative anaerobic rods and spirochetes (such as Treponema denticola) benefit from this phenomenon, especially at the base of the periodontal pocket [13]. Consequently, differences in composition and quantity of the periodontal microflora might be used to explain variations in severity of periodontitis. In spite of the difficulty of cataloguing all the members of the oral microflora and the complexity of their interactions with each other and their human host, certain species have been identified as likely perio-pathogens. For example, there is a strong body of evidence that Aggregatibacter actinomycetemcomitans, Porphyromonas gingivalis, T. denticola and Tannerella forsythia are periodontal pathogens (Slots et al., [14-19]). Whilst A. actinomycetemcomitans has been implicated to be responsible for aggressive periodontitis, $P$. gingivalis, $T$. forsythia and $T$. denticola are more associated with chronic periodontitis [20], although all four species have been implicated in various forms of periodontitis. In addition to these species, moderately strong evidence exists regarding the pathogenicity of certain other bacterial species, such as Campylobacter rectus, Eubacterium nodatum, Fusobacterium nucleatum, Parvimonas (Micromonas, Peptostreptococcus) micros, Prevotella intermedia/nigrescens, Streptococcus intermedius and various spirochetes, in some forms of periodontitis [21-29]. Taking these findings into account, the detection and quantification of a limited number of specific bacterial species in subgingival biofilms might be a helpful tool in periodontal risk assessment, determining the optimal periodontal therapy and evaluating the treatment outcome. In this study, we therefore evaluated several qPCR assays for the detection of 8 oral pathogens, i.e. Aggregatibacter actinomycetemcomitans, Fusobacterium genus, Parvimonas micros, Porphyromonas gingivalis, Prevotella intermedia, Streptococcus mutans, Tannerella forsythia and Treponema denticola. S. mutans was also included given its predominant role in the etiology of dental caries [30]. Periodontitis and caries are the most prevalent oral diseases, still resulting in considerable tooth loss [31].

\section{Methods}

\section{Bacterial strains}

The bacterial strains used in this study for analyzing sensitivity and specificity of the primers are listed in Table 1. Clinical isolates, which were not traceable to the patient, and reference isolates were used. The clinical samples used for the study mentioned that was published elsewhere [32], were covered by the ethical committee approval: B67020097225 (Belgian registration number). These clinical samples were collected from the deepest periodontal pocket per quadrant. A sterile paper point was inserted following supragingival plaque removal and left in situ for about 20 seconds. The paper points were collected in $200 \mu \mathrm{l}$ of a $20 \mathrm{mM}$ Tris $-\mathrm{HCl}, \mathrm{pH} 8$ solution (Merck, Darmstadt, Germany) and stored at $-20^{\circ} \mathrm{C}$ until DNA extraction.

\section{Extraction of DNA and preparation of standard dilution series}

Bacterial genomic DNA used for preparing standard dilution series was extracted with the High Pure PCR Template Preparation Kit (Roche, Basel, Switzerland). Briefly, all strains were grown anaerobically, except for Streptococcus spp., which were grown aerobically, on blood agar. Colonies were scraped from plates and suspended in $400 \mu \mathrm{l}$ PBS. To $200 \mu \mathrm{l}$ of bacterial suspension, $2 \mu \mathrm{l}$ mutanolysin $(25 \mathrm{U} / \mu \mathrm{l})$ was added and incubated for $15 \mathrm{~min}$ at $37^{\circ} \mathrm{C}$. Further DNA extraction was performed according to manufacturers guidelines. The DNA concentration was quantified by spectrophotometric analysis (Nanodrop, Thermo Scientific, Wilmington, DE) and converted from $\mathrm{ng} / \mathrm{ml}$ to number of genomes $/ \mathrm{ml}$ by calculating the molecular weight of the genome (ng/genome) and dividing the concentration $(\mathrm{ng} / \mathrm{ml})$ by the molecular weight of the genome in order to assign number of genome values to the standard dilution series. Bacterial DNA used for specificity testing was extracted using alkaline lysis. Briefly, strains were grown on agar plates under appropriate conditions, a single colony was picked up and dissolved in $20 \mu \mathrm{l}$ alkaline lysis buffer (0.25\% SDS, $0.05 \mathrm{~N} \mathrm{NaOH})$, the mixture was heated for $15 \mathrm{~min}$ at $95^{\circ} \mathrm{C}$, the tubes were briefly spinned, $180 \mu \mathrm{l}$ sterile HPLC water was added to neutralize the $\mathrm{pH}$, and the tubes were centrifuged during $5 \mathrm{~min}$ at $13000 \mathrm{~g}$ to spin down the bacterial cell debris. The supernatant was used as DNA extract. Tenfold standard dilution series of reference strains were made from genomic DNA extracted from A. actinomycetemcomitans DSM 11123, F. nucleatum CCUG 32989, P. micros CCUG 46357, P. gingivalis CCUG 25893, P. intermedia CCUG 24041, S. mutans LMG $14558^{\mathrm{T}}$ and $T$. forsythia CCUG $21028 \mathrm{~A}^{\mathrm{T}}$. Several attempts to grow $T$. denticola from different culture collections failed. Therefore, a tenfold standard dilution series was made of a synthetic ds oligonucleotide. We blasted the primers described by Hyvarinen et al. [33] and found that these were located on the coding domain sequence for a glycosyl transferase, corresponding to region 1470086 - 147094 of strain ATCC 35405 (GenBank: AE017226), which we ordered from Eurogentec (Liège, Belgium). All standard series were diluted in nuclease free water, containing $1 \mu \mathrm{g} / \mathrm{ml}$ 
Table 1 Bacterial strains and their corresponding collection number used to test sensitivity and specificity of the different primer pairs

\begin{tabular}{|c|c|c|}
\hline Species & Strain & Origin \\
\hline Actinobaculum schaalii & TSW25BA12a $^{\mathrm{a}}$ & human, vagina \\
\hline Actinomyces meyeri & PB2003/218-T1-6 ${ }^{\mathrm{a}}$ & human, vagina \\
\hline Actinomyces naes/undii & CCUG $18310^{\top}$ & human, sinus \\
\hline Actinomyces neuii & TSW23BA4 ${ }^{a}$ & human, vagina \\
\hline Actinomyces odontolyticus & LMG 15953 & human, drain after lung resection \\
\hline Actinomyces turicensis & TSW24BA $1^{a}$ & human, vagina \\
\hline Aggregatibacter actinomycetemcomitans & DSM 11123 & human, subgingival dental plaque \\
\hline Agrobacterium radiobacter & $01060380^{a}$ & not recorded \\
\hline Bacteroides fragilis & CCUG $4856^{\top}, 03 L 2177^{\mathrm{a}}$ & human, appendix abscess; \\
\hline Bacteroides thetaiotaomicron & CCUG 34778 & human, appendix \\
\hline Fusobacterium nucleatum & CCUG $32989^{\top}$ & human, cervico-facial lesion \\
\hline Fusobacterium varium & DSM $19868^{\top}$ & human, faeces \\
\hline Parvimonas micros & CCUG $46357^{\top}$ & human, purulent pleurisy \\
\hline Peptostreptococcus anaerobius & FWOBV0180 ${ }^{\mathrm{a}}$ & not recorded \\
\hline Porphyromonas gingivalis & CCUG $25893^{\top}$ & human, gingival sulcus \\
\hline Porphyromonas somerae & VMF0235S33 & human, vagina \\
\hline Prevotella melaninogenica & FWO BV0747 & human, vagina \\
\hline Prevotella bivia & FWO BV0913 ${ }^{\mathrm{a}}$ & human, vagina \\
\hline Prevotella buccalis & FWO BV0754 ${ }^{\mathrm{a}}$ & human, vagina \\
\hline Prevotella disiens & VMF 1000SRT31 & human, vagina \\
\hline Prevotella corporis & TSW04CA1 ${ }^{a}$ & human, vagina \\
\hline Prevotella intermedia & CCUG $24041^{\top}$ & human, empyema \\
\hline Streptococcus agalactiae & LMG $14694^{\top}$ & bovine, milk \\
\hline Streptococcus anginosus & LMG $14502^{\top}$ & human, throat \\
\hline Streptococcus mitis & LMG $14557^{\top}$ & human, oral cavity \\
\hline Streptococcus mutans & LMG $14558^{\top}$ & human, carious dentine \\
\hline Streptococcus oralis & LMG $14532^{\top}$ & human, oral cavity \\
\hline Streptococcus pneumoniae & LMG $14545^{\top}$ & not recorded \\
\hline Streptococcus pyogenes & LMG $14700^{\top}$ & not recorded \\
\hline Streptococcus sanguinis & LMG $14702^{\top}$ & human, subacute bacterial endocarditis \\
\hline Streptococcus salivarius & LMG $11489^{\top}$ & human, blood \\
\hline Streptococcus sobrinus & $\mathrm{LMG}_{14641^{\top}}$ & human, dental plaque \\
\hline Tannerella forsythia & CCUG 21028A & Human, periodontal pocket \\
\hline Treponema denticola & Oligo $^{b}$ & not applicable \\
\hline
\end{tabular}

Legend

${ }^{a}$ : Patient isolate.; ${ }^{\text {b}}: T$. denticola could not be cultured. Therefore, a ds oligonucleotide was used as template for preparing the standard series.

calf thymus DNA (Sigma-Aldrich, St. Louis, MO), according to the MIQE guidelines [34]. Calf thymus DNA was added to decrease adherence of the target DNA to the vials, in order to increase reproducibility, especially of the low concentration standards.

\section{Primers}

Primer sequences and amplicons were analysed for specificity using the nucleotide Basic Local Alignment Search Tool and primerBLAST (http://blast.ncbi.nlm. nih.gov/Blast.cgi). The presence of secondary structures was analyzed using mFOLD (http://mfold.rna.albany. edu/?q=mfold).

Table 2 lists the primers that were tested.

qPCR

Each assay was designed for most efficient amplification with the same thermocycling program: initial dsDNA denaturation (+ activation of hot start enzyme) for $10 \mathrm{~min}$ at $95^{\circ} \mathrm{C}, 40$ cycles of $15 \mathrm{~s}$ at $95^{\circ} \mathrm{C}$ and $1 \mathrm{~min}$ at $60^{\circ} \mathrm{C}$, on an ABI 7300 real time PCR system (Applied Biosystems, Carlsbad, CA). The primer concentrations 
Table 2 Primer sequences evaluated for specificity (BLAST) and primer annealing onto secondary structures (mFOLD) by in silico analysis for the eight different species

\begin{tabular}{|c|c|c|c|}
\hline Species & Primers & Target gene & Reference \\
\hline \multirow[t]{2}{*}{ Aggregatibacter actinomycetemcomitans ${ }^{a}$} & F: GCGAACGTTACGCGTTTTAC & waaA & Hyvarinen et al. [33] \\
\hline & R: GGCAAATAAACGTGGGTGAC & & \\
\hline \multirow[t]{2}{*}{ Aggregatibacter actinomycetemcomitans } & F: CTTACCTACTCTTGACATCCGAA & $16 \mathrm{~S}$ rRNA & Maeda et al. [35] \\
\hline & RV: ATGCAGCACCTGTCTCAAAGC & & \\
\hline \multirow[t]{2}{*}{ Aggregatibacter actinomycetemcomitans ${ }^{b}$} & F: CAGCATCTGCGATCCCTGTA & $i k t A$ & Yoshida et al. [36] \\
\hline & R: TCAGCCCTTTGTCTTTCCTAGGT & & \\
\hline \multirow[t]{2}{*}{ Fusobacterium spp. } & F: AAGCGCGTCTAGGTGGTTATGT & $16 \mathrm{~S}$ rRNA & Martin et al. [37] \\
\hline & R: TGTAGTTCCGCTTACCTCTCCAG & & \\
\hline \multirow[t]{2}{*}{ Fusobacterium spp.' } & F: CGCAGAAGGTGAAAGTCCTGTAT & $16 \mathrm{~S}$ rRNA & Suzuki et al. [38] \\
\hline & R: TGGTCCTCACTGATTCACACAGA & & \\
\hline \multirow[t]{2}{*}{ Parvimonas micros } & F: AAACGACGATTAATACCACATGAGAC & $16 \mathrm{~S}$ rRNA & Bartz et al. [39] \\
\hline & R: ACTGCTGCCTCCCGTAGGA & & \\
\hline \multirow[t]{2}{*}{ Parvimonas micros ${ }^{\mathrm{b}}$} & F: AGTGGGATAGCCGTTGGAAA & $16 \mathrm{~S}$ rRNA & Martin et al. [37] \\
\hline & R: GACGCGAGCCCTTCTTACAC & & \\
\hline \multirow[t]{2}{*}{ Porphyromonas gingivalis } & F: TGGTTTCATGCAGCTTCTTT & waaA & Hyvarinen et al. [33] \\
\hline & R: TCGGCACCTTCGTAATTCTT & & \\
\hline \multirow[t]{2}{*}{ Prevotella intermedia ${ }^{b}$} & F: GACCCGAACGCAAAATACAT & waaA & Hyvarinen et al. [33] \\
\hline & R: AGGGCGAAAAGAACGTTAGG & & \\
\hline \multirow[t]{2}{*}{ Prevotella intermedia } & F: TCCACCGATGAATCTITGGTC & $16 \mathrm{~S}$ rRNA & Maeda et al. [35] \\
\hline & R: ATCCAACCTTCCCTCCACTC & & \\
\hline \multirow[t]{2}{*}{ Tannerella forsythia ${ }^{a}$} & F: CTCGCTCGGTGAGTTTGAA & waaA & Hyvarinen et al. [33] \\
\hline & R: ATGGCGAAAAGAACGTCAAC & & \\
\hline \multirow[t]{2}{*}{ Tannerella forsythia } & F: GGGTGAGTAACGCGTATGTAACCT & $16 \mathrm{~S}$ rRNA & Shelburne et al. [40] \\
\hline & R: ACCCATCCGCAACCAATAAA & & \\
\hline \multirow[t]{2}{*}{ Tannerella forsythia ${ }^{b}$} & F: TCCCAAAGACGCGGATATCA & bspA antigen & Morillo et al. [41] \\
\hline & R: ACGGTCGCGATGTCATTGT & & \\
\hline \multirow[t]{2}{*}{ Tannerella forsythia ${ }^{a}$} & F: AGCGATGGTAGCAATACCTGTC & $16 \mathrm{~S}$ rRNA & Kuboniwa et al. [42] \\
\hline & R: TTCGCCGGGTTATCCCTC & & \\
\hline \multirow[t]{2}{*}{ Tannerella forsythia ${ }^{a}$} & F: ATCCTGGCTCAGGATGAACG & $16 \mathrm{~S}$ rRNA & Suzuki et al. [38] \\
\hline & R: TACGCATACCCATCCGCAA & & \\
\hline \multirow[t]{2}{*}{ Treponema denticola } & F: CCTTGAACAAAAACCGGAAA & waaG & Hyvarinen et al. [33] \\
\hline & R: GGGAAAAGCAGGAAGCATAA & & \\
\hline \multirow[t]{2}{*}{ Streptococcus mutans ${ }^{\mathrm{b}}$} & F: AGCCATGCGCAATCAACAGGTT & $g f t B$ & Yano et al. [43] \\
\hline & R: CGCAACGCGAACATCTTGATCAG & & \\
\hline \multirow[t]{2}{*}{ Streptococcus mutans } & F: GCCTACAGCTCAGAGATGCTATTCT & $g f t B$ & Yoshida et al. [36] \\
\hline & R: GCCATACACCACTCATGAATTGA & & \\
\hline
\end{tabular}

Legend

a: Primer pairs excluded for further in vitro testing on the basis of in silico analysis.

b: Primer pairs excluded for further specificity testing on the basis of amplification efficiency.

were the same for all assays, i.e. $300 \mathrm{nM}$. Assays were performed in a final volume of $25 \mu \mathrm{l}$ with a final $\mathrm{MgCl}_{2}$ concentration of $3 \mathrm{mM}$ and with $2.5 \mu \mathrm{l}$ DNA extract, using the SybrGreen qPCR core kit (Eurogentec).

Assays carried out on the LightCycler (LC) 480 thermal cycling system (Roche) were performed in a final reaction volume of $10 \mu \mathrm{l}$ with 1 or $2 \mu \mathrm{l}$ of DNA extract (both volumes were tested), using the LightCycler 480
SybrGreen I master mix, with the same primer concentrations and thermocycling program as for the ABI 7300. Assays carried out on the iQ5 thermal cycling system (Bio-Rad Laboratories, Hercules CA) were performed in a final reaction volume of $25 \mu \mathrm{l}$ with $2.5 \mu \mathrm{l}$ DNA extract, using the iQ SYBR Green Supermix, with the same primer concentrations and thermocycling program as for the ABI 7300. 


\section{Results}

The aim of this study was to optimize quantitative PCR assays (qPCR assays) for 8 important oral bacteria, i.e. Aggregatibacter actinomycetemcomitans, Fusobacterium nucleatum, Parvimonas micros, Porphyromonas gingivalis, Prevotella intermedia, Streptococcus mutans, Tanerella forsythia and Treponema denticola. In silico analysis indicated that it was not possible to develop species specific primers for F. nucleatum, based on the 16S rRNA gene. Therefore, Fusobacterium genus primers were used, assuming that - when testing oral samples - most signal strength for this qPCR will be caused by the presence of F. nucleatum, because this species is the dominant Fusobacterium species in oral microflora [44]. Different primer pairs were tested with regard to amplification efficiency, specificity and intercycler portability (robustness), i.e. portability between different thermal cyclers.

Initially, the qPCR formats were developed on an ABI 7300 thermal cycling system (Applied Biosystems), on which we first determined the amplification efficiency of the primers. Thereafter, the primer pairs with the best amplification efficiency were used to test intercycler portability by carrying out the PCRs on a LightCycler 480 thermal cycler (Roche) and on an iQ5 thermal cycler (Bio-Rad), with the same cycling parameters as used on the ABI 7300. The thermal cycler that gave the most reproducible and accurate results, was used to test the specificity of the assays.

\section{Amplification efficiency of different primer pairs}

Bioinformatic analysis (PrimerBLAST, mFold) revealed that, at an annealing temperature of $60^{\circ} \mathrm{C}$, some of the primers were annealing on secondary structures in the target genes. An example of annealing on secondary structure is shown in Figure 1 for the T. forsythia forward primer that has been proposed by Kuboniwa et al. [42].

As indicated in Table 2, we omitted these primer pairs from subsequent experiments, because annealing of the primers onto secondary structures has been shown to decrease amplification efficiency [45]. First, the amplification efficiency and quantification limit of the selected primer pairs were tested using a 10-fold standard dilution series. The best performing primer pairs were selected on the basis of amplification efficiency, correlation of standard dilution series and quantification limit, the latter defined as the lowest standard dilution that could be included in the standard series without decreasing the amplification efficiency below 95\% (Table 3). Moreover, intra-run reproducibility was taken into account (data not presented).

\section{Specificity testing}

After selection of the primer pairs that enabled amplification of the target species with the same protocol, specificity of the different primer sets was tested by including closely related species (Table 1 ) in each of the 8 qPCR assays. Assays for A. actinomycetemcomitans, $P$. micros, $P$. gingivalis and $P$. intermedia detected only the target species for which they were designed. The assay for the Fusobacterium spp. detected also F. varium, next to F. nucleatum, as expected, since this is a genus specific qPCR. For the assay for $T$. forsythia, some unspecific amplification was observed during the last cycles $\left(35<\mathrm{C}_{\mathrm{q}}<40\right)$ for strains of the species Fusobacterium nucleatum, P. bivia, P. intermedia and S. agalactiae (Figure 2). This did not affect the specificity of the T. forsythia assay because of the low amplification efficiency. Moreover, the Tm-value of the T. forsythia amplicon was situated between 81.96 and $82.02^{\circ} \mathrm{C}$, whereas Tm-values for all other species were lower. Every strain included in the specificity testing, except the strains of $P$. intermedia and $A$. radiobacter, gave weak unspecific amplification for the $T$. denticola assay. This could possibly be explained by the formation of primer dimers during the last cycles of the $T$. denticola assay, since the NTC had a high Cq value ( $>40$ ). Still, this little affected the specificity of this assay, first because of the low amplification efficiency for these nontarget species (i.e., Cq value below the quantification limit of the assay) and second because the melting profile of the unspecific PCR products was clearly different from that of the target sequence."

\section{Intercycler portability (robustness)}

After selection of the primer pairs with the highest specificity and amplification efficiency on the ABI 7300 cycler (Table 3), the same assays were carried out on the iQ5 and the LC480 thermal cyclers. In addition, for the LC480, two different DNA extract volumes, i.e. 1 and $2 \mu \mathrm{l}$ were tested. All qPCR's on the different cyclers gave good correlation of the standard series (i.e. $r^{2} \geq 0.98$ ), but quantification limits varied between cyclers. The overall best quantification limit was obtained by using a $2 \mu \mathrm{l}$ sample in a final volume of $10 \mu \mathrm{l}$ on the LC480 (Table 4).

\section{Discussion}

Although culture is currently the standard approach for assessing the oral microflora, anaerobic culture, which is required to this aim, is rather costly. Moreover, quantitative culture is very laborious, requiring more culture media, and thus an even more costly technique, with limitations of the number of samples that can be enumerated. Molecular techniques may be valuable alternatives to anaerobic quantitative culture, especially since the availability of quantitative (real-time) PCR (qPCR). Conventional PCR only reveals the presence or absence of a species, while qPCR and DNA-DNA hybridization 


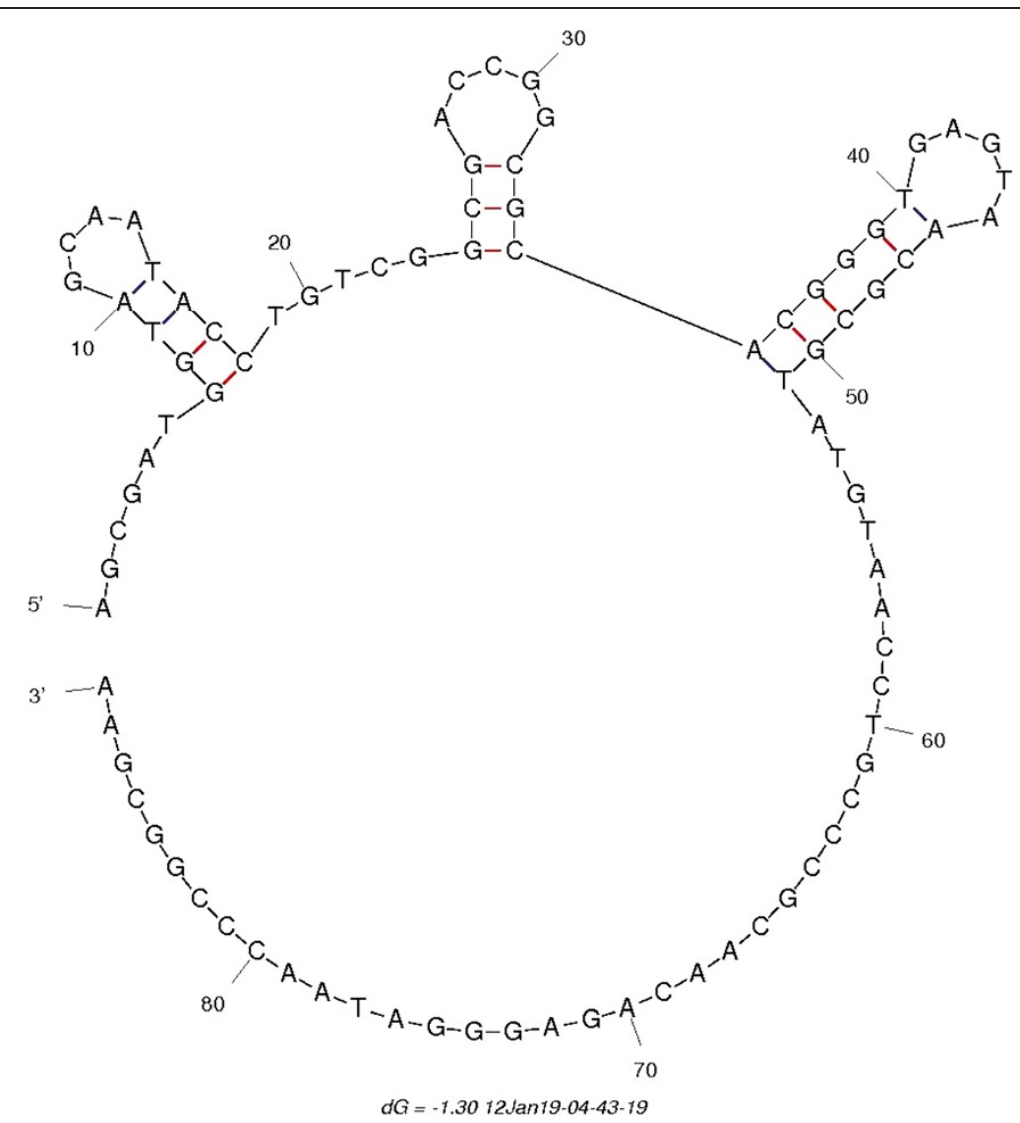

Figure 1 Analysis by mFold of the secondary structure of the Tannerella forsythia $16 \mathrm{~S}$ rRNA gene amplicon, targeted by the primers described by Kuboniwa et al. [42]. Folding conditions were adapted to gPCR conditions (see 2.4). Forward primer anneals on bp 1-22 region, which contains a hairpin (bp 7-18).

approaches (Socransky et al. [9,46]) offer (semi-)quantitative data with an acceptable degree of agreement with quantitative culture for most periodontal pathogens [47]. Although a perfect agreement between microbial enumeration techniques seems unlikely [48-50], their availability might become relevant for the clinician, especially when conventional therapeutic modalities have failed. Interestingly, microbial data could also become valuable to predict further periodontal deterioration following active treatment [51].

In order to optimize an assay to detect eight predominant oral pathogens, 8 primer pairs were selected that were run on the same thermocycling program with sufficient amplification efficiency, specificity and sufficient quantification limit. Six of the 8 assays were species specific. For the T. denticola and T. forsythia assays, some

Table 3 Primers used for specificity testing, after selection based on amplification efficiency, quantification limit, and intra-run reproducibility (data not presented)

\begin{tabular}{llll}
\hline Species (reference) & $\begin{array}{l}\text { Correlation } \\
\text { standard curve }\end{array}$ & $\begin{array}{l}\text { Amplification } \\
\text { efficiency (\%) }\end{array}$ & $\begin{array}{l}\text { Quantification limit } \\
\text { (number of bacteria } \\
\text { per 25 } \boldsymbol{\mu l} \text { reaction) }\end{array}$ \\
\hline Aggregatibacter actinomycetemcomitans [35] & 0.99 & 89 & 25 \\
\hline Fusobacterium spp. [37] & 0.99 & 94 & 4 \\
\hline Parvimonas micros [39] & 0.99 & 91 & 2 \\
\hline Porphyromonas gingivalis [33] & 0.99 & 95 & 9 \\
\hline Prevotella intermedia [35] & 0.99 & 91 & 11 \\
\hline Treponema denticola [33] & 0.99 & 95 & 150 \\
\hline Tannerella forsythia [40] & 0.99 & 93 & 25 \\
\hline Streptococcus mutans [36] & 0.98 & 115 & 37 \\
\hline
\end{tabular}




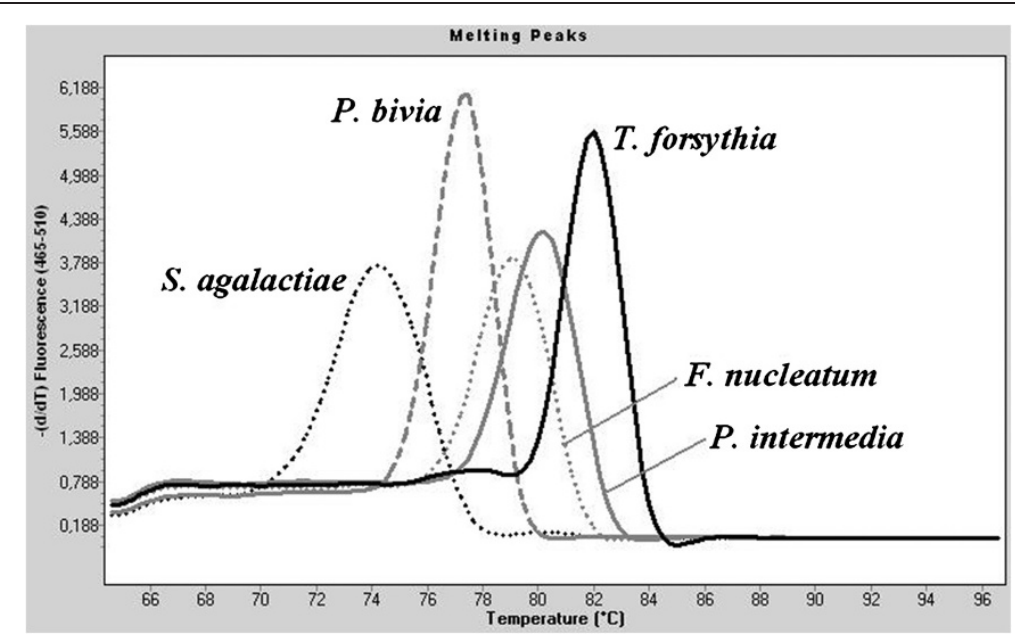

Figure 2 Melting curve analysis of unspecific amplification products for the Tannerella forsythia qPCR [40]. The melting curves presented were drawn by the software of the LC480 cycler after performing the T. forsythia qPCR on the species listed in Table 1.

unspecific amplification was observed, but only at $\mathrm{C}_{\mathrm{q}}$ values of more than 35 . This was not an issue, since the last standard included in the standard dilution series, corresponding to one chromosome/reaction for $T$. denticola and 2 chromosomes /reaction T. forsythia) had a $\mathrm{C}_{\mathrm{q}}$ value below 35, such that all fluorescence signals detected after this $\mathrm{C}_{\mathrm{q}}$ value are considered as not quantifiable. Moreover, melting curve analysis indicated that these unspecific amplification products had melting temperatures that were clearly different from that of the target species.

All assays were evaluated for intercycler portability by running the standard dilution series for each species on three different thermal cyclers, i.e. ABI 7300, Bio-Rad iQ5 and LightCycler 480. Highly efficient amplification was obtained on all cyclers, but the LightCycler 480 could detect lower bacterial inocula than the other devices, i.e. on average 3.6 chromosomes /reaction, compared to 26 chromosomes/reaction for the iQ5 and 33 chromosomes/reaction for the ABI 7300. In addition, the LightCycler 480 has higher throughput (i.e. 384 samples) than the ABI 7300 and Bio-Rad iQ5 devices (i.e. 96 samples).

The optimized assays were implemented to evaluate the microbial effects of an essential oils mouth rinse used by patients in supportive periodontal care [32]. Briefly, during a 3-month double-blind randomized placebo-controlled study, these qPCR assays were used to evaluate the microbial effects of an essential oils mouth rinse used as an adjunct approach to mechanical plaque control by patients in supportive periodontal care. Subgingival plaque samples were collected for the quantification of the 8 bacterial species by means of the qPCR formats described here. No significant differences were observed between treatment and placebo groups. Also, there was no significant change over time

Table 4 Intercycler portability of the different assays on the different thermal cyclers, by comparison of the limits of reliable quantification, i.e. the most diluted standard that could be used to calculate the standard curve, expressed here as number of cells present in the most diluted standard reaction mixture

\begin{tabular}{|c|c|c|c|c|c|}
\hline \multicolumn{2}{|l|}{ Assay } & \multirow{2}{*}{$\begin{array}{l}\text { ABI } 7300 \\
(2.5 / 22.5)^{\mathrm{a}}\end{array}$} & \multirow{2}{*}{$\begin{array}{l}\text { iQ5 } \\
(2.5 / 22.5)\end{array}$} & \multirow{2}{*}{$\begin{array}{l}\text { LC } 480 \\
(1 / 9)\end{array}$} & \multirow{2}{*}{$\begin{array}{l}\text { LC } 480 \\
(2 / 8)\end{array}$} \\
\hline Species & Reference & & & & \\
\hline Aggregatibacter actinomycetemcomitans & Maeda et al. [35] & 26 & 26 & 10 & 2 \\
\hline Fusobacterium spp. & Martin et al. [37] & 4 & 4 & 2 & 3 \\
\hline Parvimonas micros & Bartz et al. [39] & 2 & 1 & 1 & 2 \\
\hline Porphyromonas gingivalis & Hyvarinen et al. [33] & 9 & 90 & 36 & 7 \\
\hline Prevotella intermedia & Maeda et al. [35] & 11 & 11 & 4 & 9 \\
\hline Streptococcus mutans & Yoshida et al. [36] & 37 & 37 & 15 & 3 \\
\hline Tannerella forsythia & Shelburne et al. [40] & 25 & 25 & 10 & 2 \\
\hline Treponema denticola & Hyvarinen et al. [33] & 150 & 15 & 6 & 1 \\
\hline
\end{tabular}


neither in detection frequency nor load for any of the bacterial species.

\section{Conclusion}

In summary, we present optimized qPCR assays, with high intercycler portability, for direct quantification of 8 bacterial species that have been associated with periodontal disease.

\section{Competing interests}

The authors declare that they have no competing interests.

\section{Authors' contributions}

Decat E. and Saerens B. carried out the qPCR assays. Decat E. carried out the data analysis and interpretation. Decat E., Vaneechoutte M. and Van Mechelen E wrote the first draft of the manuscript. Decat E., Van Mechelen E. ,Vermeulen S., Cosyn J., Miremadi R., De Bruyn H., Vaneechoutte M. and Deschaght $P$. conceived the study, participated in its design and coordination and helped to draft the manuscript. All authors read and approved the final manuscript.

\section{Acknowledgements}

The authors thank the University College Ghent and the Flemish government for funding this study by means of the PWO project: "Study of Microbiological application for Real Time PCR (SMART)".

\section{Author details}

${ }^{1}$ Biomedical and Exact Sciences, Faculty of Education, Health \& Social Work, University College Ghent, Keramiekstraat 80, Ghent, Belgium. ²Laboratory Bacteriology Research, Department Clinical Chemistry, Microbiology \& Immunology, Faculty of Medicine and Health Sciences, University of Ghent, De Pintelaan 185, Ghent B-9000, Belgium. ${ }^{3}$ Department of Periodontology and Oral Implantology, Dental School, Faculty of Medicine and Health Sciences, University of Ghent, De Pintelaan 185, Ghent B-9000, Belgium.

Received: 3 July 2012 Accepted: 22 November 2012

Published: 2 December 2012

\section{References}

1. Loe H, Anerud A, Boysen H, Morrison E: Natural history of periodontal disease in man. Rapid, moderate and no loss of attachment in Sri Lankan laborers 14 to 46 years of age. J Clin Periodontol 1986, 13:431-445.

2. Slots J, Rams TE: Microbiology of periodontal disease. In Contemporary oral microbiology and immunology. St. Louis: Mosby Year Book; 1992:429-431.

3. Collins LM, Dawes $C$ : The surface area of the adult human mouth and thickness of the salivary film covering the teeth and oral mucosa. J Dent Res 1987, 66:1300-1302.

4. Paster BJ, Olsen I, Aas JA, Dewhirst FE: The breadth of bacterial diversity in the human periodontal pocket and other oral sites. Periodontol 2000 2006, 42:80-87.

5. Hommez GM, Verhelst R, Claeys G, Vaneechoutte M, De Moor RJ: Investigation of the effect of the coronal restoration quality on the composition of the root canal microflora in teeth with apical periodontitis by means of T-RFLP analysis. Int Endodont J 2004, 37:819-827.

6. Kumar PS, Griffen AL, Barton JA, Paster BJ, Moeschberger ML, Leys EJ: New bacterial species associated with chronic periodontitis. J Dent Res 2003, 82:338-344.

7. Moore WE, Moore LV: The bacteria of periodontal diseases. Periodontol 2000 1994, 5:66-77.

8. Paster BJ, Boches SK, Galvin JL, Ericson RE, Lau CN, Levanos VA, Sahasrabudhe A, Dewhirst FE: Bacterial diversity in human subgingival plaque. J Bacteriol 2001, 183:3770-3783.

9. Socransky SS, Haffajee AD: Periodontal microbial ecology. Periodontol 2000 2005, 38:135-187.

10. Socransky SS, Haffajee AD, Cugini MA, Smith C, Kent RL: Microbial complexes in subgingival plaque. J Clin Periodontol 1998, 25:134-144.
11. Sharawy AM, Sabharwal K, Socransky SS, Lobene RR: A quantitative study of plaque and calculus formation in normal and periodontally involved mouths. J Periodontol 1966, 37:495-501.

12. Gendron R, Grenier D, Maheu-Robert L: The oral cavity as a reservoir of bacterial pathogens for focal infections. Microbes Infect 2000, 2:897-906.

13. Kolenbrander PE, Palmer RJ Jr, Rickard AH, Jakubovics NS, Chalmers NI, Diaz PI: Bacterial interactions and successions during plaque development. Periodontol 2000 2006, 42:47-79.

14. Haffajee AD, Socransky SS, Ebersole JL, Smith DJ: Clinical, microbiological and immunological features associated with the treatment of active periodontosis lesions. J Clin Periodontol 1984, 11:600-618.

15. Haffajee AD, Socransky SS: Microbial etiological agents of destructive periodontal diseases. Periodontol 2000 1994, 5:78-111.

16. Listgarten MA, Lai CH, Evian Cl: Comparative antibody titers to Actinobacillus actinomycetemcomitans in juvenile periodontitis, chronic periodontitis and periodontally healthy subjects. J Clin Periodontol 1981, 8:155-164.

17. Slots J: Reynolds HS. Genco RJ: Actinobacillus actinomycetemcomitans in human periodontal disease: a cross-sectional microbiological investigation. Infect Immun 1980, 29:1013-1020.

18. Tanner A, Maiden MF, Macuch PJ, Murray LL, Kent RL: Microbiota of health, gingivitis, and initial periodontitis. J Clin Periodontol 1998, 25:85-98.

19. Van Winkelhoff AJ, Loos BG, van der Reijden WA, van der Velden U: Porphyromonas gingivalis, Bacteroides forsythus and other putative periodontal pathogens in subjects with and without periodontal destruction. J Clin Periodontol 2002, 29:1023-1028.

20. Socransky SS, Haffajee AD: The bacterial etiology of destructive periodontal disease: current concepts. J Periodontol 1992, 63:322-331.

21. Booth V, Downes J, Van den Berg J, Wade WG: Gram-positive anaerobic bacilli in human periodontal disease. J Periodontal Res 2004, 39:213-220.

22. Choi BK, Park SH, Yoo YJ, Choi SH, Chai JK, Cho KS, Kim CK: Detection of major putative periodontopathogens in Korean advanced adult periodontitis patients using a nucleic acid-based approach. J Periodontol 2000, 71:1387-1394.

23. Colombo AP, Teles RP, Torres MC, Souto R, Rosalem WJ, Mendes MC, Uzeda M: Subgingival microbiota of Brazilian subjects with untreated chronic periodontitis. J Periodontol 2002, 73:360-369.

24. Herrera D, Roldan S, Gonzalez I, Sanz M: The periodontal abscess (I). Clinical and microbiological findings. J Clin Periodontol 2000, 27:387-394.

25. Moore WE, Holdeman LV, Cato EP, Smibert RM, Burmeister JA, Palcanis KG, Ranney RR: Comparative bacteriology of juvenile periodontitis. Infect Immun 1985, 48:507-519.

26. Papapanou PN, Baelum V, Luan WM, Madianos PN, Chen X, Fejerskov O, Dahlen G: Subgingival microbiota in adult Chinese: prevalence and relation to periodontal disease progression. J Periodontol 1997, 68:651-666.

27. Papapanou PN, Neiderud AM, Papadimitriou A, Sandros J, Dahlen G: "Checkerboard" assessments of periodontal microbiota and serum antibody responses: a case-control study. J Periodontol 2000, 71:885-897.

28. Rams TE, Feik D, Slots J: Campylobacter rectus in human periodontitis. Oral Microbiol Immunol 1993, 8:230-235.

29. Simonson LG, Robinson PJ, Pranger RJ, Cohen ME, Morton HE: Treponema denticola and Porphyromonas gingivalis as prognostic markers following periodontal treatment. J Periodontol 1992, 63:270-273.

30. Okada M, Kawamura M, Oda Y, Yasuda R, Kojima T, Kurihara H: Caries prevalence associated with Streptococcus mutans and Streptococcus sobrinus in Japanese schoolchildren. Int J Paediatr Dent 2012, 22:342-348. Jan 8 [Epub ahead of print].

31. Richards W, Amee J, Coll AM, Higgs G: Reasons for tooth extraction in four general dental practices in South Wales. Br Dent J 2005, 198:275-278.

32. Cosyn J, Princen K, Miremadi R, Decat E, Vaneechoutte M, De Bruyn H: A double-blind randomized placebo-controlled study on the clinical and microbial effects of an essential oil mouth rinse used by patients in supportive periodontal care. Int J Dent Hyg 2012, 10.1111/ idh.12000:10.1111/idh.12000. doi:10.1111/idh.12000.

33. Hyvarinen K, Laitinen S, Paju S, Hakala A, Suominen-Taipale L, Skurnik M, Kononen E, Pussinen PJ: Detection and quantification of five major periodontal pathogens by single copy gene-based real-time PCR. Innate Immun 2009, 15:195-204

34. Bustin SA, Benes V, Garson JA, Hellemans J, Huggett J, Kubista M, Mueller R, Nolan T, Pfaffl MW, Shipley GL, Vandesompele J, Wittwer CT: The MIQE 
guidelines: Minimum Information for publication of Quantitative realtime PCR Experiments. Clin Chem 2009, 55:611-622.

35. Maeda H, Fujimoto C, Haruki Y, Maeda T, Kokeguchi S, Petelin M, Arai H, Tanimoto I, Nishimura F, Takashiba S: Quantitative real-time PCR using TaqMan and SYBR Green for Actinobacillus actinomycetemcomitans, Porphyromonas gingivalis, Prevotella intermedia, tetQ gene and total bacteria. FEMS Immunol Med Microbiol 2003, 39:81-86.

36. Yoshida A, Suzuki N, Nakano Y, Kawada M, Oho T, Koga T: Development of a 5 ' nuclease-based real-time PCR assay for quantitative detection of cariogenic dental pathogens Streptococcus mutans and Streptococcus sobrinus. J Clin Microbiol 2003, 41:4438-4441.

37. Martin FE, Nadkarni MA, Jacques NA, Hunter N: Quantitative microbiological study of human carious dentine by culture and real-time PCR: Association of anaerobes with histopathological changes in chronic pulpitis. J Clin Microbiol 2002, 40:1698-1704.

38. Suzuki N, Yoshida A, Nakano Y: Quantitative analysis of multi-species oral biofilms by taqman real-time PCR. Clin Med Res 2005, 3:176-185.

39. Bartz H, Nonnenmacher C, Bollmann C, Kuhl M, Zimmermann S, Heeg K, Mutters R: Micromonas (Peptostreptococcus) micros: unusual case of prosthetic joint infection associated with dental procedures. Int J Med Microbiol 2005, 294:465-470.

40. Shelburne CE, Prabhu A, Gleason RM, Mullally BH, Coulter WA: Quantitation of Bacteroides forsythus in subgingival plaque - Comparison of immunoassay and quantitative polymerase chain reaction. J Microbiol Methods 2000, 39:97-107.

41. Morillo JM, Lau L, Sanz M, Herrera D, Martin C, Silva A: Quantitative realtime polymerase chain reaction based on single copy gene sequence for detection of periodontal pathogens. J Clin Periodontol 2004, 31:1054-1060.

42. Kuboniwa M, Amono A, Kimura KR, Sekine S, Kato S, Yamamoto Y, Okahashi $\mathrm{N}$, Lida T, Shizukuishi S: Quantitative detection of periodontal pathogens using real-time polymerase chain reaction with TaqMan probes. Oral Microbiol Immunol 2004, 19:168-176.

43. Yano A, Kaneko N, Ida H, Yamaguchi T, Hanada N: Real-time PCR for quantification of Streptococcus mutans. FEMS Microbiol Lett 2002, 217:23-30.

44. Signat B, Roques $C$, Poulet $P$, Duffaut D: Role of Fusobacterium nucleatum in periodontal health and disease. Curr Issues Mol Biol 2011, 13:25-35.

45. Hoebeeck J, Speleman F, Vandesompele J: Real-time quantitative PCR as an alternative to Southern blot or fluorescence in situ hybridization for detection of gene copy number changes, Methods in Molecular Biology. Volume 353. New Jersey: Humana Press; 2007:205-226.

46. Persson RG, Hitti J, Verhelst R, Vaneechoutte M, Persson RE, Hirschi R, Weibel M, Rothen M, Temmerman M, Paul K, Eschenbach D: The vaginal microflora in relation to gingivitis. BMC Infect Dis 2009, 9:6.

47. Haffajee AD, Yaskell T, Torresyap G, Teles R, Socransky SS: Comparison between polymerase chain reaction-based and checkerboard DNA hybridization techniques for microbial assessment of subgingival plaque samples. J Clin Periodontol 2009, 36:642-649.

48. Boutaga K, van Winkelhoff AJ, Vandenbroucke-Grauls CM, Savelkoul PH: Comparison of real-time PCR and culture for detection of Porphyromonas gingivalis in subgingival plaque samples. J Clin Microbiol 2003, 41:4950-4954.

49. Boutaga K, van Winkelhoff AJ, Vandenbroucke-Grauls CM, Savelkoul PH: Periodontal pathogens: a quantitative comparison of anaerobic culture and real-time PCR. FEMS Immunol Med Microbiol 2005, 45:191-199.

50. Boutaga K, Savelkoul PH, Winkel EG, Van Winkelhoff AJ: Comparison of subgingival bacterial sampling with oral lavage for detection and quantification of periodontal pathogens by real-time polymerase chain reaction. J Periodontol 2007, 78:79-86.

51. Rams TE, Listgarten MA, Slots J: Utility of 5 major putative periodontal pathogens and selected clinical parameters to predict periodontal breakdown in patients on maintenance care. J Clin Periodontol 1996, 23:346-354

\section{doi:10.1186/1756-0500-5-664}

Cite this article as: Decat et al: Optimization of quantitative polymerase chain reactions for detection and quantification of eight periodontal bacterial pathogens. BMC Research Notes 2012 5:664. 